\title{
The Relative Efficacy of Thermal and Acidification Stresses on the Survival of E. coli O157:H7, Salmonella, and Listeria Monocytogenes in Ground Beef
}

\author{
Sagor Biswas ${ }^{1} \&$ Pramod Pandey ${ }^{1}$ \\ ${ }^{1}$ Department of Population Health and Reproduction, School of Veterinary Medicine, University of California \\ Davis, California 95616, USA \\ Correspondence: Pramod Pandey, Department of Population Health and Reproduction, School of Veterinary \\ Medicine, 1089 Veterinary Medicine Derive, University of California-Davis, California 95616, USA. Tel: \\ 530-752-0615. E-mail: pkpandey@ucdavis.edu
}

Received: March 14, 2017

Accepted: April 8, 2017 Online Published: April 25, 2017

doi:10.5539/jfr.v6n3p74

URL: https://doi.org/10.5539/jfr.v6n3p74

\begin{abstract}
To provide additional insights on pathogen survival, we evaluated the relative efficacy of acidification ( $\mathrm{pH} 2.7$ ), thermophilic treatment $\left(55^{\circ} \mathrm{C}\right)$, and low temperature pasteurization $\left(68{ }^{\circ} \mathrm{C}\right)$ on the inactivation of $E$. coli 0157:H7, Salmonella, and Listeria monocytogenes in ground beef. A series of experiment was conducted under biosafety level 3 environments for assessing the impacts of heat and low $\mathrm{pH}$ on pathogen survival. Results showed that 5-log reductions of E. coli $\mathrm{O} 157: \mathrm{H} 7$ could take more than 2640 min at $55^{\circ} \mathrm{C}, 134 \mathrm{~min}$ at $68{ }^{\circ} \mathrm{C}$ and 120 min under $\mathrm{pH}$ 2.7. Compared to E. coli O157:H7, the 5-log reduction of Salmonella was obtained in 4836, $126,86 \mathrm{~min}$ at $55^{\circ} \mathrm{C}, 68^{\circ} \mathrm{C}$, and $\mathrm{pH} 2.7$, respectively. The 5-log reduction of Listeria was achieved in 4704, 200, and 115 min under $55^{\circ} \mathrm{C}, 68{ }^{\circ} \mathrm{C}$, and $\mathrm{pH} 2.7$, respectively. The results of this study will provide additional insights for developing improved methods for controlling pathogens in ground beef.
\end{abstract}

Keywords: foodborne pathogens, thermal inactivation, acidification, ground beef, public health

\section{Introduction}

The U.S. Centers for Disease Control and Prevention (CDC) estimates that each year 48 million people in the U.S. are sickened by foodborne diseases, which results in 128,000 hospitalizations, and 3,000 deaths (National Center for Emerging and Zoonotic Infectious Diseases, 2016). More than 10-80 billion USD are involved annually in dealing with foodborne outbreaks in the U.S. (Bavaro, 2012). Each year approximately 73,000-97,000 and 37,000-169,000 illnesses are linked with Shiga toxin-producing and non-Shiga toxin-producing E. coli, respectively (CDC, 2011; Luchansky et al., 2014; Scallan et al., 2011). In addition to E. coli, Listeria monocytogenes causes more than 255 deaths annually. Further, Salmonella spp. alone is responsible for more than 1 million illnesses annually (Scallan et al., 2011). A foodborne diseases active surveillance network study conducted in 10 U.S. sites reported that Salmonella was the most common infectious pathogen between 1996 and 2010 (CDC, 2011).

Over the past 30 years, many illnesses and at least six outbreaks were related to Shiga toxin-producing $E$. coli O157:H7 in beef products (Beauchamp \& Sofos, 2010; Luchansky et al., 2014). After the 1992-1993 multistate outbreaks of E. coli O157:H7, the United States Department of Agriculture (USDA) Food Safety Inspection Service (FSIS) enforced zero tolerance for E. coli O157:H7 in ground beef and trim, which was followed by mandated Hazard Analysis and Critical Control Point (HACCP) regulation (Wheeler, Kalchayanand, \& Bosilevac, 2014).

In addition to various $E$. coli serogroups such as $\mathrm{O} 157$ and non-O157 (O26, O123, O111, O145, O45), which are already added to the list of adulterates in beef, a debate is ongoing on how to include Salmonella (Wheeler et al., 2014) in this group. Listeria monocytogenes is known for its ability to grow at even refrigeration temperature, which results in significant food safety issue (Pal, Labuza, \& Diez-Gonzalez, 2008; Rhoades, Duffy, \& Koutsoumanis, 2009). The rate of fatalities during Listeria monocytogenes is relatively higher in comparison with E. coli and Salmonella. For example, 78 (11.35\%) of the 687 fatalities between 1996 and 2000 in the England and Wales were related to Listeria monocytogenes; while Listeria was the agent in only $221(0.01 \%)$ of 
1.7 million reported cases of foodborne illness (Adak, Meakins, Yip, Lopman, \& O'Brien, 2005; Rhoades et al., 2009).

Although considerable regulations are in place for reducing the risk of pathogens in beef products in the U.S. and outside of the U.S., the prevalence of E. coli O157:H7, Salmonella, and Listeria monocytogenes are not uncommon. For instance, Rhoades et al. (2009) reported the mean prevalence of E. coli O157 in $44 \%$ hides, $0.3 \%$ chilled carcasses, and $1.2 \%$ raw beef products. The prevalence of Salmonella was reported in $60 \%$ hides, $1.3 \%$ chilled carcasses, and 3.8\% raw beef products. The mean prevalence of Listeria monocytogenes was reported in $12 \%$ hides, and $10 \%$ raw beef products (Rhoades et al., 2009). Cattle hides are considered to be the main source of carcass contamination during cattle processing (Arthur et al., 2007). The author reported that the prevalence of E. coli $\mathrm{O} 157: \mathrm{H} 7$ in hides varied from 50 to $94 \%$. Another study reported the prevalence of $E$. coli $\mathrm{O} 157: \mathrm{H} 7$ and Salmonella on $46.9 \%$ and $89.9 \%$ of cattle hides, respectively (Brichta-Harhay et al., 2008). On average 33.3\% of cattle hide were contaminated by both pathogens. The prevalence of Listeria monocytogenes was reported in $10.8 \%$ of hide samples (Wieczorek, Dmowska, \& Osek, 2012).

To control the pathogens in ground beef, methods including acidification, radio frequency, and thermal treatment are reported. The inactivation results of foodborne pathogens in ground beef by the energy of radio frequency indicated that the cooking of meatballs with the combination of radio frequency and convection cooking reduced the levels of E. coli O157:H7, Salmonella, and Listeria monocytogenes to the non-detectable levels in 5.5 minutes (Schlisselberg et al., 2013). It has also been reported that the efficacy of treatments with regards to pathogen inactivation changes with products and strains (Vasan, Geier, Ingham, \& Ingham, 2014). The authors found significant differences in decimal reduction of E. coli among various strains at $55{ }^{\circ} \mathrm{C}$. The time for Salmonella decimal reduction was found to be significantly less than $\mathrm{O} 157$ and non-O157 Shiga toxigenic E. coli (Vasan et al., 2014).

A study focused on understanding of the fate of Listeria monocytogenes and Salmonella during preparation of ground beef jerky showed that the population of both the organisms was reduced by 4-3 orders of magnitudes, respectively, in 480 minutes of drying at $60^{\circ} \mathrm{C}$. The acid treatments for reducing E. coli O157:H7and Listeria monocytogenes levels in beef trim were found to be effective (Conner, Kotrola, Mikel, \& Tamblyn, 1997). The authors reported that the use of 2 and $4 \%$ acid spray in beef trim stored at $4{ }^{\circ} \mathrm{C}$ reduced Listeria monocytogenes (initial concentrations $3 \log _{10} \mathrm{CFU} / \mathrm{g}$ ) by $0.36 \log _{10} \mathrm{CFU} / \mathrm{g}$ and $0.44 \log _{10} \mathrm{CFU} / \mathrm{g}$, respectively. The reduction in E. coli O157:H7 was lower than Listeria monocytogenes under similar conditions (Conner et al., 1997).

Another study by Juneja (Juneja \& Eblen, 1999) reported that lowering the $\mathrm{pH}$ increases the heat sensitivity of Listeria monocytogenes in beef slurry. Despite these numerous studies, which were executed in last decades, additional understanding is still needed to improve the inactivation of E. coli O157:H7, Salmonella, and Listeria monocytogenes in ground beef, particularly, when ground beef is mixed continuously during cooking, and moisture content is high. Therefore, the goal of this study was to enhance the understanding of how acid and heat treatments influences E. coli O157:H7, Salmonella, and Listeria monocytogenes inactivation in ground beef under high moisture and continuous mixing conditions. The specific objectives were to: 1) study the relative efficacy of thermophilic temperature $\left(55^{\circ} \mathrm{C}\right)$ on the inactivation of E. coli $\mathrm{O} 157: \mathrm{H} 7$, Salmonella, and Listeria monocytogenes; 2) assess the inactivation of E. coli O157:H7, Salmonella, and Listeria monocytogenes under low temperature pasteurization $\left(68^{\circ} \mathrm{C}\right)$ condition; and 3) determine the survival pattern of these pathogens under low $\mathrm{pH}(\approx 2.7)$ condition. Subsequently, models were developed to understand the relationships between time-temperature-pathogen inactivation and to predict the required time for pathogen reduction by 5-order of magnitude.

\section{Materials and Methods}

\subsection{Beef Feedstock Preparation and Experiment Setup}

The beef (chuck boneless eye steak) used for this experiment was purchased from the local grocery store (Walmart, Dixon, CA). The characteristics of beef (total nitrogen, protein, crude fat, and ash content) were analyzed (shown in Table 1). These parameters were analyzed at the University of California (UC) Davis Analytical Lab using the standard protocol (UC Davis Analytical Laboratory, 2015). Prior to starting the experiment, the beef was stored at $-20^{\circ} \mathrm{C}$ in the Extension Lab of School of Veterinary Medicine, University of California- Davis. To prepare the feedstock for the experiment, the beef was thawed with water, and subsequently, $200 \mathrm{~g}$ of beef was weighted and mixed with $800 \mathrm{ml}$ of deionized (DI) water in the blending machine (Ninja Ultima Blender, Model BL800, 1500 Watt/ 2.5 peak HP motor). The experiment was conducted inside a biosafety cabinet (level III) to minimize the pathogen risks to the personnel involved in the experiment as well as possible ambient contamination. Two $1 \mathrm{~L}$ glass beakers were used as reactors for the experiment. 
These two reactors were designated as two replicates (R1 and R2) for each set of experiment (i.e., thermophilic, low temperature pasteurization, and acidification). The glass beakers were placed in the water bath under exactly similar conditions (Figure 1). To control the temperature of the beef slurry in the two reactors used for digestion, the temperature of the water bath was regulated. The stirring of the beef slurry was performed using two overhead mixers (CAFRAMO, Model BDC250U1) in all the three stages. During the thermophilic and pasteurization processes, stirring speed was 50 RPM, and during the acidification process, the stirring speed was 200 RPM to create the uniformity in the temperature and digestion conditions of beef slurry emulsion. Stirring also created an aerated environment within the reactors.

Table 1. Properties of beef used for the experiment

\begin{tabular}{ll}
\hline Content & Mean \pm Standard Deviation (\%) \\
\hline N (Total) & $13.8 \pm 0.1$ \\
\hline Protein & $86.0 \pm 0.4$ \\
\hline Crude Fat & $14.3 \pm 0.3$ \\
\hline Ash & $3.5 \pm 0.0$ \\
\hline
\end{tabular}

NOTE: Protein results are based on the factor for alfalfa.

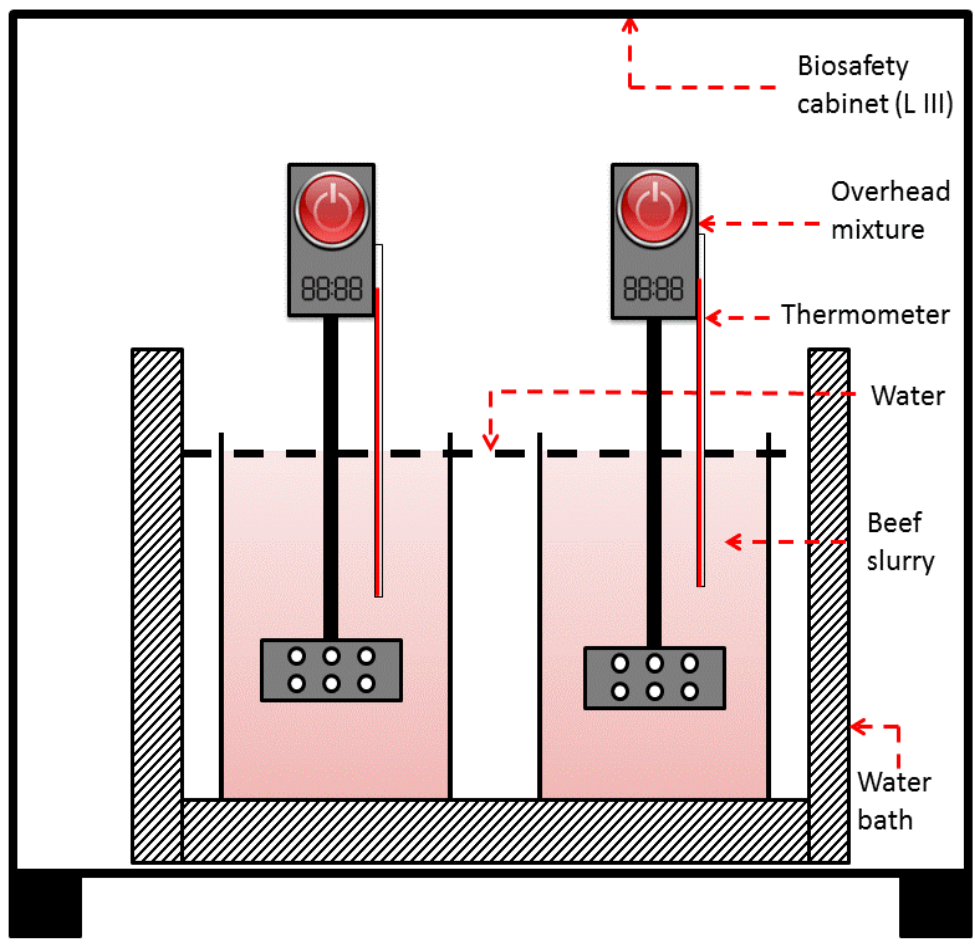

Figure 1. The experimental setup of water bath, beakers and overhead mixer inside the biosafety cabinet

Using the experiment setup shown in Figure 1, a series of experiments were conducted to test the inactivation of E. coli O157, Salmonella Typhimurium LT2, and Listeria monocytogenes under multiple incubation conditions. To test the impacts of heat stress, the incubations were performed at $55{ }^{\circ} \mathrm{C}$ (thermophilic) and $68{ }^{\circ} \mathrm{C}$ (low temperature pasteurization). For testing the impacts of acidification, the feedstock $\mathrm{pH}$ was lowered to 2.7 using phosphoric acid. The incubation at $55^{\circ} \mathrm{C}$ was performed for 4 days $(5640 \mathrm{~min} \approx 94 \mathrm{~h})$. The incubation under low temperature pasteurization condition $\left(68^{\circ} \mathrm{C}\right)$ was conducted for $210 \mathrm{~min}(3.5 \mathrm{~h})$. The acidification experiment was executed for $2 \mathrm{~h}$.

\subsection{Pathogen Inoculation and Testing}

To test pathogen inactivation, the beef slurry was inoculated with known concentrations of human pathogens $(E$. coli O157:H7, Salmonella enterica serovar Typhimurium LT2, and L. monocytogenes) at room temperature. To prepare inoculum of these pathogens, the fresh pathogen cultures of E. coli 0157:H7 (ATCC \#35150), S. typhimurium LT2 (ATCC \#700720), and L. monocytogenes (ATCC \# BAA- 679D-5) were prepared in the lab prior to starting the experiment. Difco LB Broth Miller (Luria-Bertani) growth media was used for growing $E$. 
coli $\mathrm{O} 157: \mathrm{H} 7$ and S. typhimurium LT2. BBL Brain Heart Infusion was used for growing L. monocytogenes. The overnight cell growths of these pathogens in respective media were used to form the pellets (by centrifugation) of each pathogen. A $4 \mathrm{ml}$ volume of pure culture of each pathogen was pelletized using micro-centrifuge (Thermo Scientific, Sorvall Legend X1R, Langenselbold, Germany) at 8000 RPM for 10 min. Subsequently, the cell pellets were dissolved into the beef slurry, and mixed $10 \mathrm{~min}$ at room temperature.

The pathogen-inoculated beef slurry was digested under thermophilic and pasteurization temperature to understand the pathogen inactivation in ground beef. The acidification experiment was performed at room temperature $\left(22{ }^{\circ} \mathrm{C}\right)$, while other two experiments at desired temperature (i.e., 55 and $68{ }^{\circ} \mathrm{C}$ ) conditions. Samples were collected from the experimental digesters over the period of experiments, and pathogens levels were analyzed within $24 \mathrm{~h}$ of sample collection. Pathogens were enumerated using selective agar media following the FDA BAM method (Biswas, Pandey, \& Farver, 2016; Pandey et al., 2016; USFDA, 2016).

For pathogen enumeration, the digested beef slurry samples were streaked (i.e., plated) on MacConkey II Agar (Becton, Dickinson and Company, Sparks, MD, USA), Difco XLD Agar (Becton, Dickinson and Company, Sparks, MD, USA), and PALCAM Agar (with selective supplement) (HiMedia Laboratory Pvt Ltd, Mumbai, India) plates for testing the concentrations of E. coli O157:H7, S. typhimurium LT2, and L. monocytogenes, respectively. Total number of samples collected in thermophilic, pasteurization, and acidification were 26, 20, and 18, respectively. All the samples were tested in duplicates. During the acidification study, food grade phosphoric acid was used to reduce the $\mathrm{pH}$ of beef slurry. The total of $5 \mathrm{ml}$ phosphoric acid $\left(\mathrm{H}_{3} \mathrm{PO}_{4}\right)$ was used for reducing the $\mathrm{pH}$ from 5.9 to 2.7 in each reactor. A pH meter (Omega Engineering, INC., Stamford, CT, USA) equipped with a $\mathrm{pH}$ and temperature probe was used to measure the $\mathrm{pH}$ and temperature during the experiment.

\subsection{Data Analysis}

Data analyses were performed in GraphPad Prism 6 and Microsoft Excel 2010 software. Descriptive statistics (average, standard deviation, minimum, maximum) were calculated in Excel. The function "analyze" of GraphPad Prism 6 was used to compare the slopes of linear curves of inactivation data of E. coli O157:H7, Salmonella, and Listeria monocytogenes. The linear regression and 95\% confidence bands were used to compare the data. The linear regression equations of pathogen inactivation obtained from GraphPad Prism 6 (2016) were used to predict the time required for 5-log reduction of each pathogen.

\section{Results and Discussion}

\subsection{Change in Temperature and pH During Experiment}

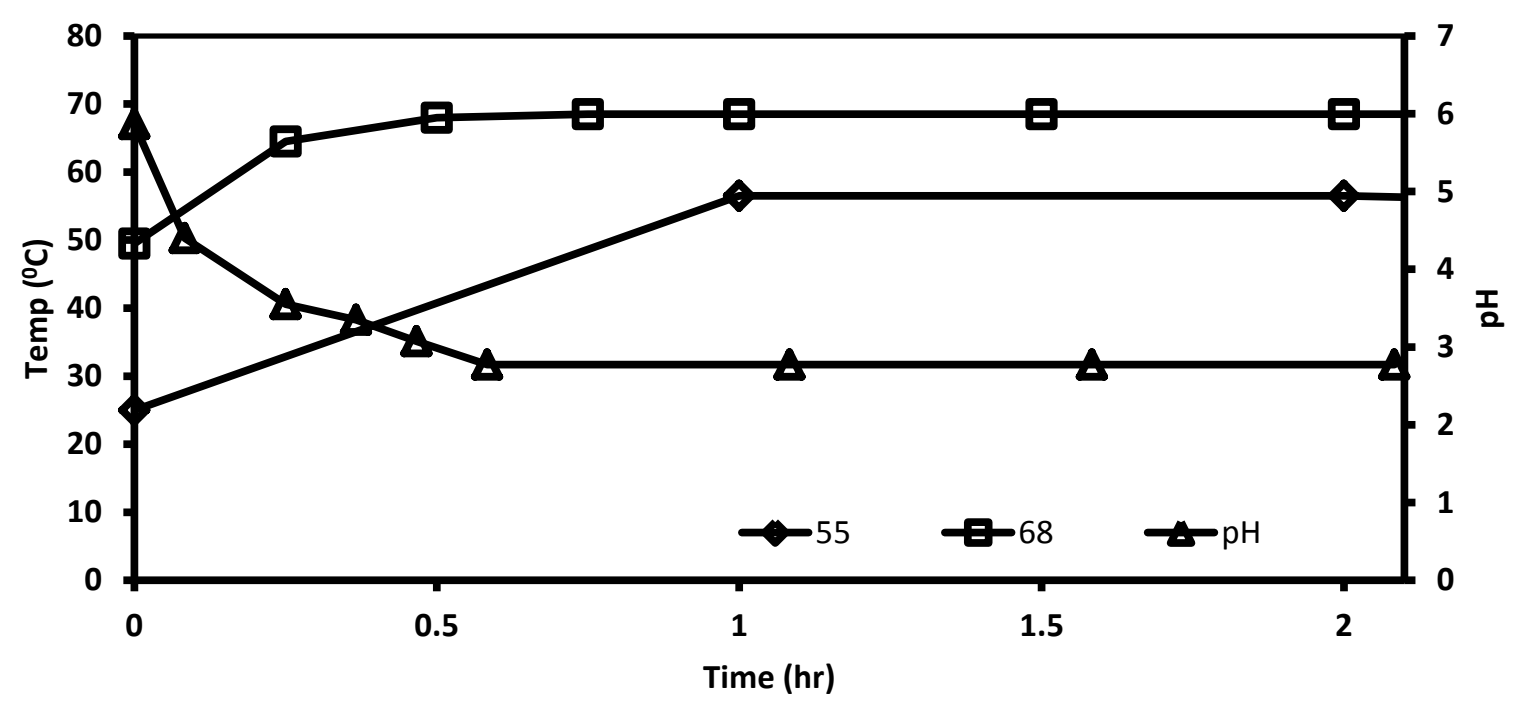

Figure 2. Change in temperature and $\mathrm{pH}$ at thermophilic, pasteurization and acidification experiments

Figure 2 shows the temperature profile during the thermophilic and pasteurization processes and change in $\mathrm{pH}$ of the acidification experiment in a single graph. For thermophilic process $\left(55^{\circ} \mathrm{C}\right)$, it took $1 \mathrm{~h}$ to raise the slurry temperature to $55{ }^{\circ} \mathrm{C}$ from room temperature $\left(25{ }^{\circ} \mathrm{C}\right)$. During this process water bath temperature was maintained at $55^{\circ} \mathrm{C}$. During pasteurization $\left(68{ }^{\circ} \mathrm{C}\right)$ experiment, the temperature of the beef slurry was increased 
to $50{ }^{\circ} \mathrm{C}$ within short period after placing the beakers in water bath (maintained at $68{ }^{\circ} \mathrm{C}$ ), the temperature increased from $50{ }^{\circ} \mathrm{C}$ to $68{ }^{\circ} \mathrm{C}$ in 30 min (Figure 2). During acidification process, the $\mathrm{pH}$ drop was relatively sudden after phosphoric acid was added to slurry.

\subsection{Observations of Pathogens Reduction at Thermophilic Stage $\left(55^{\circ} \mathrm{C}\right)$}

The changes in E. coli $\mathrm{O} 157$, Salmonella, and Listeria monocytogenes concentrations over time at $55{ }^{\circ} \mathrm{C}$ are shown in Figure 3. The total duration for the inactivation procedure was set $94 \mathrm{~h}$. During the first $6 \mathrm{~h}$ of experiment, samples were collected hourly and then once daily for the next 3 days. The initial concentration of $E$. coli $\mathrm{O} 157$ was $9.6 \log _{10} \mathrm{CFU} / \mathrm{ml}$. Subsequently, there was a sharp decline (4.2-log reduction) during the first $6 \mathrm{~h}$ of experiment. There was only 3-log reduction in next $50 \mathrm{~h}$, which indicates that the majority of pathogens were reduced within first $6 \mathrm{~h}$ of experiment. There was no E. coli $\mathrm{O} 157$ positive sample in the beef slurry at the end of experiment.

The initial concentration of Salmonella in beef slurry was $10 \log _{10} \mathrm{CFU} / \mathrm{ml}$. There was a 3.2-log reduction in the first $6 \mathrm{~h}$. A total of 5.6-log reduction was achieved at the end of experiment. Among the pathogens, Salmonella survival was longer compared to the $E$. coli at $55^{\circ} \mathrm{C}$. The initial concentration of Listeria was $9.3 \log _{10} \mathrm{CFU} / \mathrm{ml}$. There was a 3-log reduction in concentration of Listeria in beef slurry over the first $6 \mathrm{~h}$ of experiment and total $5.4 \log$ reduction at the end of experiment.

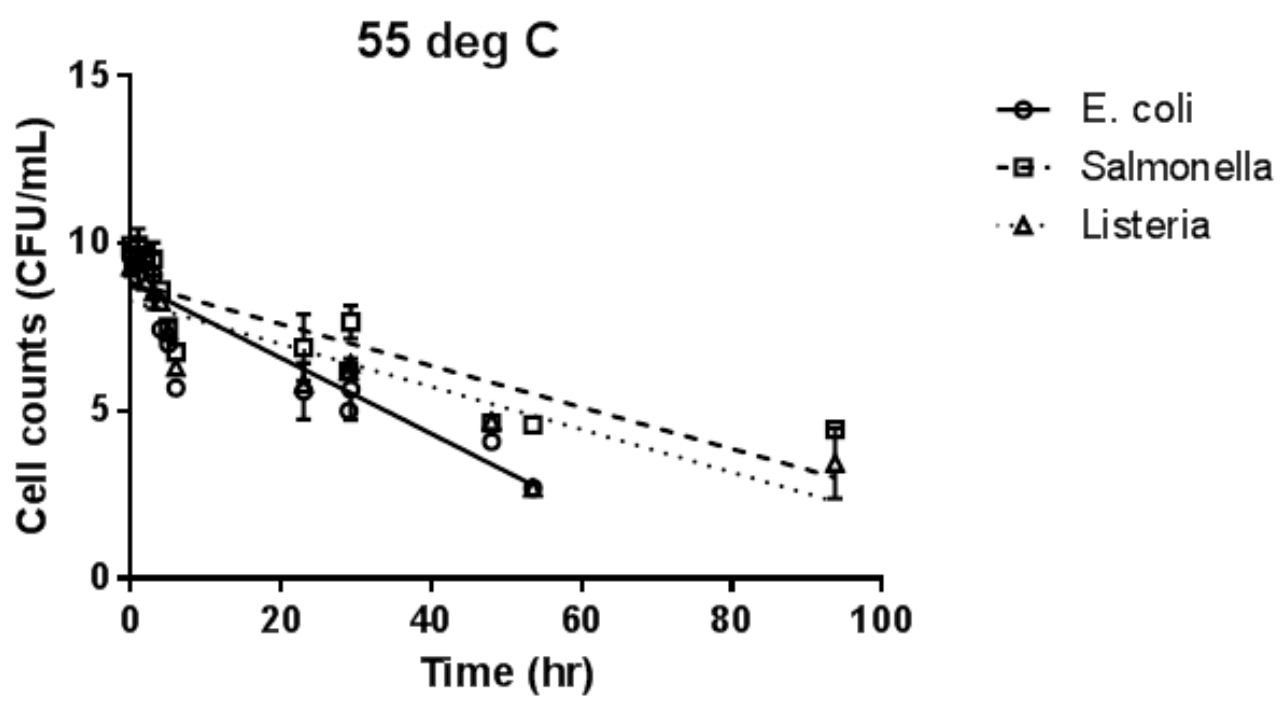

Figure 3. Change in concentrations of E. coli $\mathrm{O} 157: \mathrm{H} 7$, Salmonella and Listeria monocytogenes over time at $55^{\circ} \mathrm{C}$

\subsection{Observations of Pathogens Reduction in Pasteurization Temperature $\left(68^{\circ} \mathrm{C}\right)$}

The change in E.coli O157, Salmonella, and Listeria monocytogenes concentrations at $68^{\circ} \mathrm{C}$ is shown in Figure 4. At $68{ }^{\circ} \mathrm{C}$, the samples were collected at $15 \mathrm{~min}$ interval during the first hour of experiment and at $30 \mathrm{~min}$ interval beyond $60 \mathrm{~min}$ of digestions to the end of experiment. The reduction of E.coli O157 was gradual and went to undetectable level by the end of experiment in both the reactors. The starting concentration of $E$. coli O157 in beef slurry was $9.8 \log _{10} \mathrm{CFU} / \mathrm{ml}$. There was a 5.4-log reduction during the first 90 min of experiment. The total duration of experiment was $3.5 \mathrm{~h}$. The concentration of E.coli $\mathrm{O} 157$ was reduced to undetectable level after $3 \mathrm{~h}$.

The initial concentration of Salmonella was $9.7 \log _{10} \mathrm{CFU} / \mathrm{ml}$. There was a 6.5 -log reduction of Salmonella concentration at $68{ }^{\circ} \mathrm{C}$ during the first 90 min of experiment. Salmonella levels reached to undetected level at the end of experiment. The initial concentration of Listeria was $9.4 \log _{10} \mathrm{CFU} / \mathrm{ml}$. There was a $4.4 \log$ reduction in Listeria concentration over the period of $90 \mathrm{~min}$. At the end of the experiment, Listeria concentrations were undetectable in digested samples. 


\section{$68 \operatorname{deg} C$}

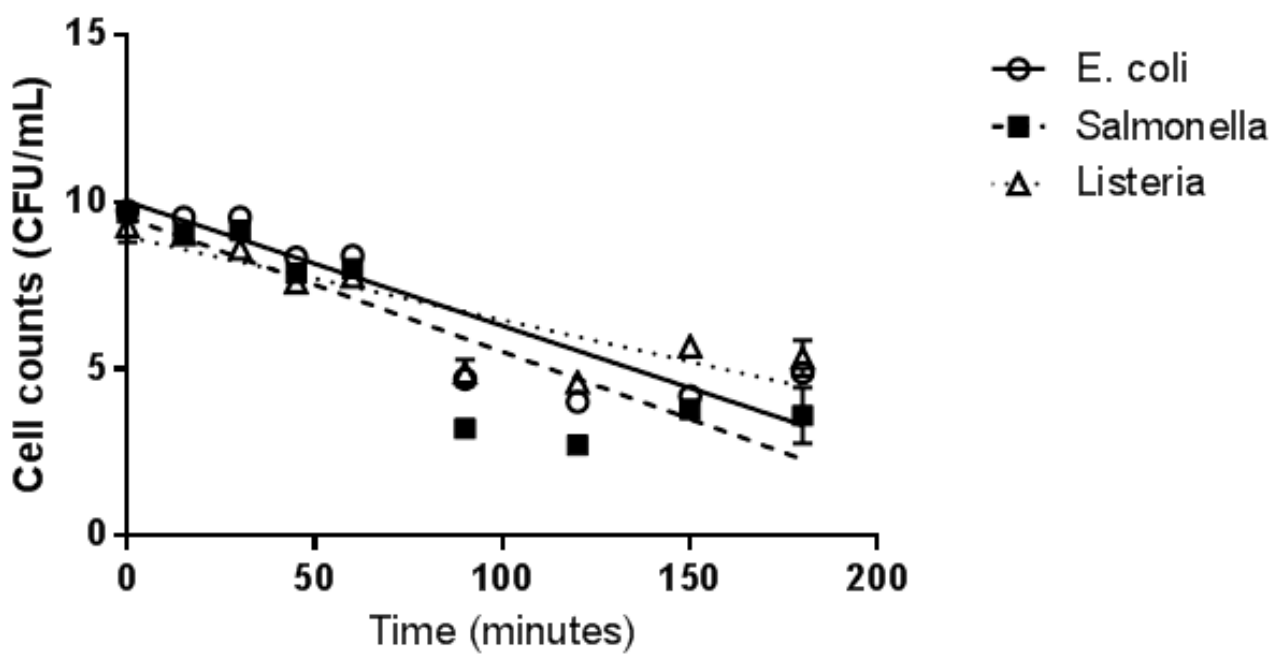

Figure 4. Change in concentrations of E. coli O157:H7, Salmonella and Listeria monocytogenes over time at $68{ }^{\circ} \mathrm{C}$

\subsection{Observations of Pathogens Reduction in Acidification}

The change in E. coli O157, Salmonella, and Listeria monocytogenes concentrations over the time is shown in Figure 5. During the acidification phase, we gradually added $1 \mathrm{ml}$ of phosphoric acid $\left(\mathrm{H}_{3} \mathrm{PO}_{4}\right)$ to observe the reduction of $\mathrm{pH}$. The initial $\mathrm{pH}$ of beef slurry was 5.87 (Figure 2). The initial concentration of E. coli $\mathrm{O} 157$ was $9.4 \log _{10} \mathrm{CFU} / \mathrm{ml}$. The results showed that by gradually adding $5 \mathrm{ml}$ of phosphoric acid, the $\mathrm{pH}$ dropped to 2.77 in $30 \mathrm{~min}$. A $5.7 \mathrm{log}$ reduction of E. coli $\mathrm{O} 157$ was observed compared with the initial concentration. The initial concentration of Salmonella was $9.6 \log _{10} \mathrm{CFU} / \mathrm{ml}$. Salmonella concentration was reduced by $6.9-\log$ in $35 \mathrm{~min}$ after adding $5 \mathrm{ml}$ of phosphoric acid. The initial concentration of Listeria was $8.6 \log _{10} \mathrm{CFU} / \mathrm{ml}$, and 3.4-log reduction was observed after adding the $5 \mathrm{ml}$ of phosphoric acid, which resulted in a drop of slurry pH to 3.1. During acidification, Listeria concentration was reduced by 4.9-log by the end of experiment.

\subsection{Statistical Analysis and Prediction of Desired Time for 5-Log Reduction in Concentration}

The concentrations of the three pathogens at each sampling event are reported as average concentrations of two samples obtained from the two reactors. The summary of the quantitative results of regression analysis is provided in Table 2 . The results showed that $E$. coli 0157:07 will take relatively shorter time to inactivate at $55^{\circ} \mathrm{C}$ compared to Salmonella and Listeria monocytogenes. The trend line slope was higher for E. coli $\mathrm{O} 157: \mathrm{H} 7$ $(-0.11)$ compared to Salmonella $(-0.06)$ and Listeria $(-0.06)$. The regression analysis showed better $r^{2}$ value for $E$. coli $\mathrm{O} 157: \mathrm{H} 7$ (0.81) compared with Salmonella (0.71) and Listeria (0.75). There was a significant $(\mathrm{P}<0.05)$ difference in slopes between E. coli O157:H7 versus Salmonella, and E. coli O157:H7 versus Listeria (i.e., 95\% confidence intervals did not overlap). However, there are no significant differences between Salmonella versus Listeria monocytogenes (confidence interval did overlap).

The summary of the best fit lines at the inactivation temperature of $68{ }^{\circ} \mathrm{C}$ are also provided in Table 2. The regression lines show that Salmonella takes relatively shorter time to inactivate at $68{ }^{\circ} \mathrm{C}$ compared with E. coli O157: $\mathrm{H} 7$ and Listeria monocytogenes. All the three pathogens seem to show similar inactivation patterns. The slope of the trend line was higher for Salmonella (-0.040) and E. coli O157:H7 (-0.037) compared with Listeria (-0.025). The regression lines showed $r^{2}$ value of $0.84,0.79$, and 0.91 for E. coli O157:H7, Salmonella, and Listeria, respectively. There was no significant difference between slopes of E. coli O157:H7, Salmonella, and Listeria.

The results of regression analysis of acidification are provided in Table 2. The regression shows that E. coli O157:H7 takes relatively shorter time for inactivation during acidification compared with Salmonella and Listeria monocytogenes. The slope of the regression line was higher for E. coli O157:H7 (-0.089) compared to Salmonella (-0.058) and Listeria (-0.043). The regression fit lines showed $\mathrm{r}^{2}$ values of E. coli O157:H7 (0.86), Salmonella $(0.77)$, and Listeria $(0.81)$. There was a significant $(P<0.05)$ difference in slopes between $E$. coli and Listeria. There are no significant $(P<0.05)$ differences between Salmonella and Listeria. Also there was no significant $(P<0.05)$ differences between E.coli and Salmonella inactivation (confidence interval did overlap). 


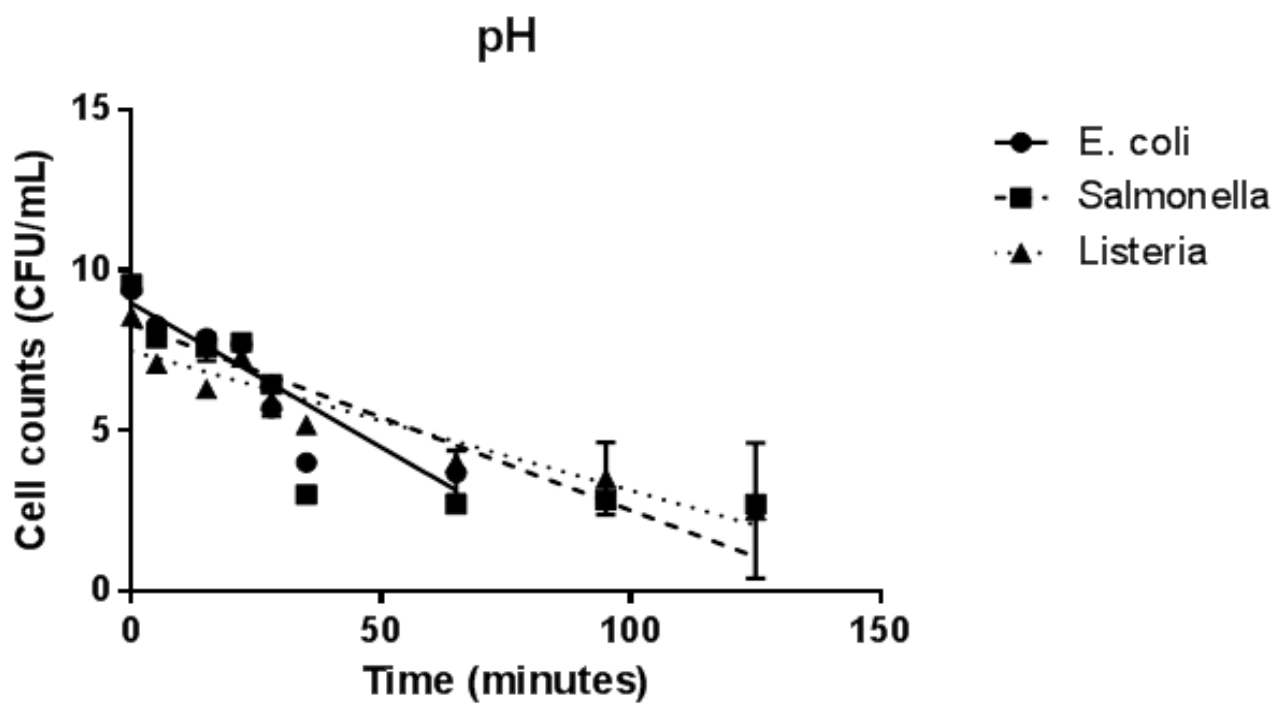

Figure 5. Change in concentrations of E. coli O157:H7, Salmonella and Listeria monocytogenes over time during acidification phase

Table 2. Statistical summary of the inactivation lines of E. coli O157:H7, Salmonella, and Listeria monocytogenes at $55^{\circ} \mathrm{C}, 68^{\circ} \mathrm{C}$, and acidification

\begin{tabular}{lrrr}
\hline Best-fit values & Ecoli $\mathrm{O} 157: \mathrm{H} 7$ & Salmonella & Listeria monocytogenes \\
\hline $55^{\circ} \mathrm{C}$ & $\mathrm{Y}=-0.1132 * \mathrm{X}+8.853$ & $\mathrm{Y}=-0.06202 * \mathrm{X}+8.835$ & $\mathrm{Y}=-0.06379 * \mathrm{X}+8.279$ \\
Equation & -0.1403 to -0.08613 & -0.07874 to -0.04530 & -0.08029 to -0.04730 \\
Slope $(95 \%$ Confidence Intervals) & 0.8110 & 0.7096 & 0.7451 \\
$\mathrm{R}$ square & $<0.0001$ & $<0.0001$ & $<0.0001$ \\
$\mathrm{P}$ value & & & \\
$68^{\circ} \mathrm{C}$ & $\mathrm{Y}=-0.03723 * \mathrm{X}+10.01$ & $\mathrm{Y}=-0.04026 * \mathrm{X}+9.535$ & $\mathrm{Y}=-0.02493 * \mathrm{X}+8.954$ \\
Equation & -0.04740 to -0.02705 & -0.05174 to -0.02879 & -0.03281 to -0.01705 \\
Slope $(95 \%$ Confidence Intervals) & 0.8411 & 0.7885 & 0.7518 \\
R square & $<0.0001$ & $<0.0001$ & $<0.0001$ \\
P value & & & \\
Acidification & & & \\
Equation & $\mathrm{Y}=-0.08977 * \mathrm{X}+8.974$ & $\mathrm{Y}=-0.05811 * \mathrm{X}+8.321$ & $\mathrm{Y}=-0.04348 * \mathrm{X}+7.482$ \\
Slope $(95 \%$ Confidence Intervals) & -0.1137 to -0.06584 & -0.07700 to -0.03922 & -0.05460 to -0.03236 \\
R square & 0.8611 & 0.7726 & 0.8111 \\
P value & $<0.0001$ & $<0.0001$ & $<0.0001$ \\
\hline
\end{tabular}

The statistic and log linear regression equations of pathogen inactivation in thermophilic, pasteurization, and acidification processes are shown in Table 2. The model based on log linear regressions were used to determine the required time for 5-log reduction of E. coli, Salmonella, and Listeria during thermophilic, pasteurization, and acidification processes. Figure 6 shows estimated inactivation time for 5-log reduction of each pathogen. At $55{ }^{\circ} \mathrm{C}$, the desired inactivation time for 5-log reductions of E. coli $\mathrm{O} 157$ was found to be $44.2 \mathrm{~h}$ compared to $80.6 \mathrm{~h}$ for Salmonella and $78.4 \mathrm{~h}$ for Listeria monocytogenes. Previous studies found quicker pathogen destruction time compared to the current study. Doyle and Schoeni (1984) observed the log reduction time of $39.8 \mathrm{~min}$ for E.coli $\mathrm{O} 157: \mathrm{H7}$ in ground beef at $54.5^{\circ} \mathrm{C}(\mathrm{pH}$ of 5.7), and $0.16 \mathrm{~min}$ of $\log$ reduction time for E.coli 0157:H7 at $64.3{ }^{\circ} \mathrm{C}$ at $\mathrm{pH} 5.7$ with $0.25 \mathrm{NaCl}$ solutions. Line et al. (1991) detected that the log reduction time varied between $4-7.4 \mathrm{~min}$ at $57^{\circ} \mathrm{C}$ in lean and fatty beef and $0.2-0.5 \mathrm{~min}$ at $63{ }^{\circ} \mathrm{C}$ while the initial concentration of E.coli O157:H7 was 6-7 $\log _{10} \mathrm{CFU} / \mathrm{g}$ in the inoculated ground lean or fatty beef. In a similar study, Vijay K Juneja, Snyder, and Marmer (1997) inoculated beef with E.coli O157:H7 and found log reduction time of 21.5 min at $55{ }^{\circ} \mathrm{C}$ and approximately $0.4 \mathrm{~min}$ at $65{ }^{\circ} \mathrm{C}$. To investigate the thermal inactivation of E.coli $\mathrm{O} 157$ in ground beef, OrtaRamirez et al. (1997) found log reduction time of 46.1, 6.4, .04, and $0.1 \mathrm{~min}$ at 53, 58, 63, and $68{ }^{\circ} \mathrm{C}$. Guo, Piyasena, Mittal, Si, and Gong (2006) used non-pathogenic E.coli K12 to evaluate the influence of cooking on the inactivation of E.coli in ground beef and showed that no E.coli/ coliform (initial concentration 
$\left.<10^{3} \mathrm{CFU} / \mathrm{g}\right)$ or E.coli $\mathrm{K} 12\left(10^{7} \mathrm{CFU} / \mathrm{g}\right)$ was detected after $4.5 \mathrm{~min}$ of radiofrequency cooking or $152 \mathrm{~min}$ of water bath cooking at $72{ }^{\circ} \mathrm{C}$. In this study at $68{ }^{\circ} \mathrm{C}$, the estimated 5-log reductions time for E. coli $\mathrm{O} 157$ and Salmonella was determined to be 134.3 and $124.2 \mathrm{~min}$, respectively. While studying Salmonella inactivation, OrtaRamirez et al. (1997) found the log reduction time of 53, 15.2, 2.1, and $0.2 \mathrm{~min}$ in ground beef at 53, 58, 63, and $68{ }^{\circ} \mathrm{C}$, respectively. V. K. Juneja, Eblen, and Ransom (2001) found 9 min of log reduction time at $58{ }^{\circ} \mathrm{C}$ and around $1 \mathrm{~min}$ of $\log$ reduction time at $65^{\circ} \mathrm{C}$ for beef (12.5\% fat), which was with inoculated with Salmonella spp. Craven and Blankenship (1983) observed the log reduction time of 0.9 min for Salmonella spp in Beef at $60{ }^{\circ} \mathrm{C}$ at $5.9 \mathrm{pH}$ with $0.23 \mathrm{NaCl}$ solution. Murphy, Duncan, Johnson, Davis, and Smith (2002) studied the thermal inactivation of Salmonella serotypes and Listeria innocua in different meat products and found that the $\log$ reduction time was $9.09 \mathrm{~min}$ in beef patties at $55^{\circ} \mathrm{C}$ and $0.97 \mathrm{~min}$ at $65^{\circ} \mathrm{C}$ while the initial concentration of Salmonella was $7-8 \log _{10} \mathrm{CFU} / \mathrm{g}$.

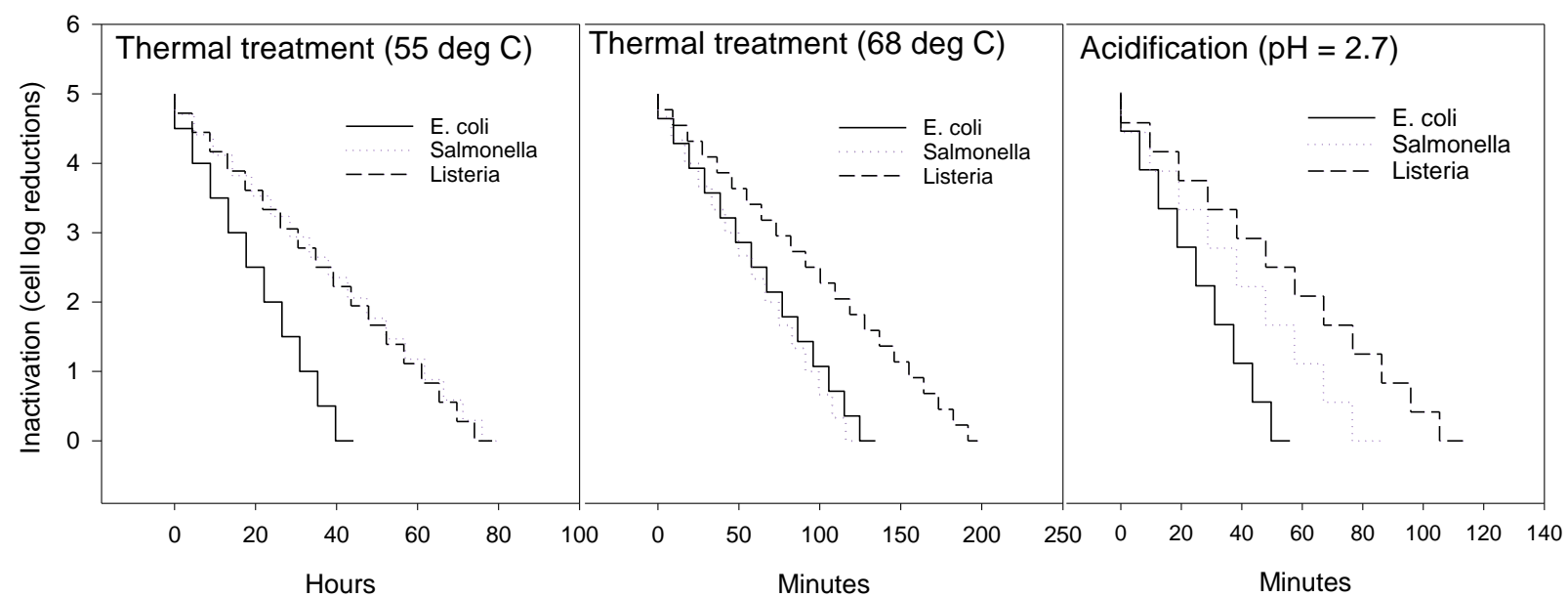

Figure 6. Estimated inactivation time for 5-log reduction of E. coli O157:H7, Salmonella, and Listeria monocytogenes under heat treatment and low $\mathrm{pH}$ conditions

From projected calculation, the $5 \log$ reduction of Listeria at $68{ }^{\circ} \mathrm{C}$ will occur in $200 \mathrm{~min}$. Hansen and Knochel (1996) observed the log reduction time of $27-29 \mathrm{~min}$ at $56^{\circ} \mathrm{C}$ and about $2 \mathrm{~min}$ at $64{ }^{\circ} \mathrm{C}$ when evaluating the thermal inactivation of Listeria monocytogenes in minced beef. In the previous study by Murphy et al. (2002), where the initial concentration of Listeria was 7-8 $\log _{10} \mathrm{CFU} / \mathrm{g}$, the $\log$ reduction time was $19.52 \mathrm{~min}$ at $55{ }^{\circ} \mathrm{C}$ and $0.76 \mathrm{~min}$ at $65{ }^{\circ} \mathrm{C}$. Vijay K Juneja (2003) found the log reduction time of $0.75 \mathrm{~min}$ at $65{ }^{\circ} \mathrm{C}$ in inoculated ground beef with Listeria monocytogenes (initial concentrations of 8-9 $\log _{10} \mathrm{CFU} / \mathrm{ml}$ ). In inoculated ground beef with known concentration (9 $\left.\log _{10} \mathrm{CFU} / \mathrm{ml}\right)$ of Listeria monocytogenes, Huang (2009) observed that it took about $2 \mathrm{~min}$ to achieve 5 -log reduction at $63{ }^{\circ} \mathrm{C}$ and about $30 \mathrm{~min}$ at $57^{\circ} \mathrm{C}$. Above studies showed considerable differences in required inactivation time among various pathogens in heat treatment.

Previous studies by de W Blackburn, Curtis, Humpheson, Billon, and McClure (1997) hypothesized that increase in acidity or alkalinity can increase the rate of inactivation of pathogens such as Salmonella enteritidis and E.coli O157:H7. During acidification phase of this study, however, the inactivation of each pathogen was relatively greater in lower incubation time. The estimated 5-log reduction times for E. coli O157, Salmonella and Listeria monocytogenes were found to be 55.9, 86.0, and $115 \mathrm{~min}$, respectively. Vijay K Juneja and Eblen (1999) determined the effects of temperature, $\mathrm{pH}$, salt, and sodium phosphate on the inactivation of Listeria monocytogenes in beef slurry. Authors found that at $55^{\circ} \mathrm{C}$ while the $\log$ reduction time was $5.35 \mathrm{~min}$ at $\mathrm{pH} 4$, it was $21.64 \mathrm{~min}$ at $\mathrm{pH} 8$ (i.e., reduced time under low $\mathrm{pH}$ ). Authors also showed that at $65^{\circ} \mathrm{C}$ the $\log$ reduction time was $0.26 \mathrm{~min}$ at $\mathrm{pH} 4$ and $0.24 \mathrm{~min} \mathrm{pH} 8$.

\section{Conclusions}

In this experiment, we studied the relative efficacy of thermal and acidification treatments on the inactivation of E.coli O157, Salmonella, and Listeria monocytogenes in ground beef. The relative inactivation of pathogens was studied for $94 \mathrm{~h}$ at $55^{\circ} \mathrm{C}, 3.5 \mathrm{~h}$ at $68{ }^{\circ} \mathrm{C}$ and $2 \mathrm{~h}$ for $\mathrm{pH} 2.77$. Observations were used to develop regression equations, which predict the time required for 5-log reduction of E. coli O157:H7, Salmonella, and Listeria at $55^{\circ} \mathrm{C}, 68^{\circ} \mathrm{C}$ and $\mathrm{pH}$ 2.7. Results showed that time required for 5-log reduction changes with temperature and species. For Salmonella, 5-log reductions at $55^{\circ} \mathrm{C}, 68^{\circ} \mathrm{C}$, and pH 2.77 were obtained at $80.6 \mathrm{~h}, 2.1 \mathrm{~h}$, and $1.43 \mathrm{~h}$, 
respectively. Similar reductions in Listeria were achieved at $78.4 \mathrm{~h}, 3.33 \mathrm{~h}$, and $1.92 \mathrm{~h}$, respectively. The concentration of E. coli was reduced by $5-\log$ in $44,2.2$, and $2 \mathrm{~h}$ at $55{ }^{\circ} \mathrm{C}, 68{ }^{\circ} \mathrm{C}$ and $\mathrm{pH} 2.7$, respectively. We anticipate that the results of this study will be useful for improving the existing models capable of predicting the various pathogen inactivations under different treatment conditions such as acidification, pasteurization, and thermophilic environment.

\section{Acknowledgments}

The authors thank the Division of Agriculture and Natural Resources, Veterinary Medicine School Extension, and University of California Cooperative Extension (UCCE) for supporting this work. Authors also appreciate Dr. Philip Kass, Professor in the Department of Population Health and Reproduction, School of Veterinary Medicine, University of California, Davis for his feedback in the use of statistical model.

\section{References}

Adak, G. K., Meakins, S. M., Yip, H., Lopman, B. A., \& O'Brien, S. J. (2005). Disease risks from foods, England and Wales, 1996-2000. Emerging Infectious Diseases, 11(3), 365-372. https://doi.org/10.3201/eid1103.040191

Arthur, T. M., Bosilevac, J. M., Brichta-Harhay, D. M., Guerini, M. N., Kalchayanand, N., Shackelford, S. D., ... Koohmaraie, M. (2007). Transportation and lairage environment effects on prevalence, numbers, and diversity of Escherichia coli O157: $\mathrm{H} 7$ on hides and carcasses of beef cattle at processing. Journal of Food Protection ${ }^{\circledR}, 70(2), 280-286$. https://doi.org/10.4315/0362-028X-70.2.280

Bavaro, M. F. (2012). E. coli O157: $\mathrm{H} 7$ and other toxigenic strains: the curse of global food distribution. Current gastroenterology reports, 14(4), 317-323. https://doi.org/10.1007/s11894-012-0264-6

Beauchamp, C. S., \& Sofos, J. N. (2010). Diarrheagenic Escherichia coli. chap, 5, 71-94. https://doi.org/10.1128/9781555815936.ch5

Biswas, S., Pandey, P. K., \& Farver, T. B. (2016). Assessing the impacts of temperature and storage on Escherichia coli, Salmonella, and L. monocytogenes decay in dairy manure. Bioprocess and Biosystems Engineering, 39(6), 901-913. https://doi.org/10.1007/s00449-016-1569-x

Brichta-Harhay, D. M., Guerini, M. N., Arthur, T. M., Bosilevac, J. M., Kalchayanand, N., Shackelford, S. D., ... Koohmaraie, M. (2008). Salmonella and Escherichia coli O157: H7 contamination on hides and carcasses of cull cattle presented for slaughter in the United States: an evaluation of prevalence and bacterial loads by immunomagnetic separation and direct plating methods. Applied and Environmental Microbiology, 74(20), 6289-6297. https://doi.org/10.1128/AEM.00700-08

CDC. (2011, June 10). Vital signs: incidence and trends of infection with pathogens transmitted commonly through food-foodborne diseases active surveillance network, 10 US sites, 1996-2010 (1545-861X). Retrieved December 24, 2016, from https://www.cdc.gov/mmwr/preview/mmwrhtml/mm6022a5.htm

Conner, D., Kotrola, J., Mikel, W., \& Tamblyn, K. (1997). Effects of acetic-lactic acid treatments applied to beef trim on populations of Escherichia coli O157: H7 and Listeria monocytogenes in ground beef. Journal of Food Protection ${ }^{\circledR}, 60(12), 1560-1563$. https://doi.org/10.4315/0362-028X-60.12.1560

Craven, S. E., \& Blankenship, L. C. (1983). Increased Heat Resistance of Salmonella in Beef with Added Soy Proteins. Journal of Food Protection, 46(5), 380-384. https://doi.org/10.4315/0362-028X-46.5.380

De W Blackburn, C., Curtis, L., Humpheson, L., Billon, C., \& McClure, P. (1997). Development of thermal inactivation models for Salmonella enteritidis and Escherichia coli O157: H7 with temperature, $\mathrm{pH}$ and $\mathrm{NaCl}$ as controlling factors. International Journal of Food Microbiology, 38(1), 31-44. http://doi.org/10.1016/S0168-1605(97)00085-8

National Center for Emerging and Zoonotic Infectious Diseases. (2016, August 19). Estimates of Foodborne Illness in the United States. Retrieved December 10, 2016, from http://www.cdc.gov/foodborneburden/index.html

Doyle, M. P., \& Schoeni, J. L. (1984). Survival and Growth-Characteristics of Escherichia-Coli Associated with Hemorrhagic Colitis. Applied and Environmental Microbiology, 48(4), 855-856.

Graphphad Prism 6. (2016). Retrived June 24, 2016, from https://www.graphpad.com/

Guo, Q., Piyasena, P., Mittal, G. S., Si, W., \& Gong, J. (2006). Efficacy of radio frequency cooking in the reduction of Escherichia coli and shelf stability of ground beef. Food Microbiology (London), 23(2), 112-118. https://doi.org/10.1016/j.fm.2005.02.004 
Hansen, T. B., \& Knochel, S. (1996). Thermal inactivation of Listeria monocytogenes during rapid and slow heating in sous vide cooked beef. Letters in Applied Microbiology, 22(6), 425-428. https://doi.org/10.1111/j.1472-765X.1996.tb01195.x

Huang, L. (2009). Thermal inactivation of Listeria monocytogenes in ground beef under isothermal and dynamic temperature conditions. Journal of Food Engineering, 90(3), 380-387. https://doi.org/10.1016/j.jfoodeng.2008.07.011

Juneja, V. K. (2003). Predictive model for the combined effect of temperature, sodium lactate, and sodium diacetate on the heat resistance of Listeria monocytogenes in beef. Journal of Food Protection $®$, 66(5), 804-811. https://doi.org/10.4315/0362-028X-66.5.804

Juneja, V. K., \& Eblen, B. S. (1999). Predictive thermal inactivation model for Listeria monocytogenes with temperature, $\mathrm{pH}, \mathrm{NaCl}$, and sodium pyrophosphate as controlling factors. Journal of Food Protection ${ }^{\circledR}$, 62(9), 986-993. https://doi.org/10.4315/0362-028X-62.9.986

Juneja, V. K., Eblen, B. S., \& Ransom, G. M. (2001). Thermal inactivation of Salmonella spp. in chicken broth, beef, pork, turkey, and chicken: Determination of D- and Z-values. Journal of Food Science, 66(1), 146-152. https://doi.org/10.1016/j.fm.2008.01.009

Juneja, V. K., Snyder, O. P., \& Marmer, B. S. (1997). Thermal destruction of Escherichia coli O157: H7 in beef and chicken: determination of D-and z-values. International Journal of Food Microbiology, 35(3), 231-237. https://doi.org/10.1016/S0168-1605(96)01237-8

Line, J. E., Fain, A. R., Moran, A. B., Martin, L. M., Lechowich, R. V., Carosella, J. M., \& Brown, W. L. (1991). Lethality of Heat to Escherichia-Coli O157-H7 - D-Value and Z-Value Determinations in Ground-Beef. Journal of Food Protection, 54(10), 762-766. https://doi.org/10.4315/0362-028X-54.10.762

Luchansky, J. B., Porto-Fett, A., Shoyer, B. A., Thippareddi, H., Amaya, J. R., \& Lemler, M. (2014). Thermal inactivation of Escherichia coli O157: H7 and non-O157 Shiga toxin-producing Escherichia coli cells in mechanically tenderized veal. Journal of Food Protection $®$, 77(7), 1201-1206. https://doi.org/10.4315/0362-028X.JFP-13-414

Murphy, R., Duncan, L., Johnson, E., Davis, M., \& Smith, J. (2002). Thermal inactivation D-and z-values of Salmonella serotypes and Listeria innocua in chicken patties, chicken tenders, franks, beef patties, and blended beef and turkey patties. Journal of Food Protection ${ }^{\circledR}, 65(1), 53-60$. https://doi.org/10.4315/0362-028X-65.1.53

OrtaRamirez, A., Price, J. F., Hsu, Y. C., Veeramuthu, G. J., CherryMerritt, J. S., \& Smith, D. M. (1997). Thermal inactivation of Escherichia coli O157:H7, Salmonella senftenberg, and enzymes with potential as time-temperature indicators in ground beef. Journal of Food Protection, 60(5), 471-475. https://doi.org/10.4315/0362-028X-60.5.471

Pal, A., Labuza, T. P., \& Diez-Gonzalez, F. (2008). Comparison of primary predictive models to study the growth of Listeria monocytogenes at low temperatures in liquid cultures and selection of fastest growing ribotypes in meat and turkey product slurries. Food microbiology, 25(3), 460-470. https://doi.org/10.1016/j.fm.2008.01.009

Pandey, P., Lejeune, M., Biswas, S., Morash, D., Weimer, B., \& Young, G. (2016). A new method for converting foodwaste into pathogen free soil amendment for enhancing agricultural sustainability. Journal of Cleaner Production, 112, 205-213. https://doi.org/10.1016/j.jclepro.2015.09.045

Rhoades, J., Duffy, G., \& Koutsoumanis, K. (2009). Prevalence and concentration of verocytotoxigenic Escherichia coli, Salmonella enterica and Listeria monocytogenes in the beef production chain: a review. Food Microbiology, 26(4), 357-376. https://doi.org/10.1016/j.fm.2008.10.012

Scallan, E., Hoekstra, R. M., Angulo, F. J., Tauxe, R. V., Widdowson, M.-A., Roy, S. L., ... Griffin, P. M. (2011). Foodborne illness acquired in the United States-major pathogens. Emerging Infectious Diseases, 17(1). https://doi.org/10.3201/eid1701.p11101

Schlisselberg, D. B., Kler, E., Kalily, E., Kisluk, G., Karniel, O., \& Yaron, S. (2013). Inactivation of foodborne pathogens in ground beef by cooking with highly controlled radio frequency energy. International Journal of Food Microbiology, 160(3), 219-226. https://doi.org/10.1016/j.ijfoodmicro.2012.10.017

USFDA. (2016). Bacteriological Analytical Manual (BAM). Laboratory Methods. Retrieved March 23, 2016, from http://www.fda.gov/Food/FoodScienceResearch/LaboratoryMethods/ucm2006949.htm 
Vasan, A., Geier, R., Ingham, S. C., \& Ingham, B. H. (2014). Thermal tolerance of O157 and non-O157 Shiga toxigenic strains of Escherichia coli, Salmonella, and potential pathogen surrogates, in frankfurter batter and ground beef of varying fat levels. Journal of Food Protection $®$, 77(9), 1501-1511. https://doi.org/10.4315/0362-028X.JFP-14-106

Wheeler, T. L., Kalchayanand, N., \& Bosilevac, J. M. (2014). Pre- and post-harvest interventions to reduce pathogen contamination in the U.S. beef industry. Meat Science, 98(3), 372-382.

https://doi.org/10.1016/j.meatsci.2014.06.026

Wieczorek, K., Dmowska, K., \& Osek, J. (2012). Prevalence, characterization, and antimicrobial resistance of Listeria monocytogenes isolates from bovine hides and carcasses. Applied and Environmental Microbiology, 78(6), 2043-2045. https://doi.org/10.1128/AEM.07156-11

\section{Copyrights}

Copyright for this article is retained by the author(s), with first publication rights granted to the journal.

This is an open-access article distributed under the terms and conditions of the Creative Commons Attribution license (http://creativecommons.org/licenses/by/4.0/). 